\title{
Effect of the Amount of Water on the Extraction of Coconut Milk at Two Temperature Ranges
}

\author{
L. E. Cancel, J. M. Rivera-Ortiz, and M. Santos-Sanchez ${ }^{1}$
}

\section{INTRODUCTION AND REVIEW OF LITERATURE}

Coconut milk is used widely in food preparation. Palad $(17),{ }^{2}$ noted that 10 of 18 native coconut-based dishes from the Philippines are prepared by adding coconut milk, seven use fresh-grated coconut pulp, and one the sweetened dehydrated product. Cabanillas et al. (4) and Aboy-de-Valldejuli (1) show that in Puerto Rico, out of 22 dishes known to contain coconut, 12 are prepared from coconut milk and 10 from fresh-grated coconut pulp. Popper et al. (18) suggest use of coconut mill in preparation of the new nondairy, cheese-type products developed by the Western Utilization Research and Development Division of USDA. Coconut-based recipes presented by the Coconut Research Institute of Ceylon (8) indicate the use of coconut milk in half of the formulas suggested. Coconut milk and coconut pulp thus are accepted and established as generalized forms in food formulation and preparation.

Coconut mill is prepared by comminuting the coconut pulp with or without addition of water and pressing the comminuted pulp. The variables affecting the efficiency of the extraction and composition of the coconut milk so obtained are numerous. Differences in the composition of the nut pulp are due to the stage of maturity of the fruit (13), varietal differences (14) and cultural practices (3). These variables are not within the scope of processors. Factors such as the size reduction, water addition, temperature of extraction, and pressure of dewatering can be controlled during the processing operation, however, to obtain an economic yield and a good quality product.

Early reports in the literature show great variation in the information available concerning the water and fat content of coconut milk $(18,15,16$, 12).

Luke (12), in discussing the preparation of coconut milk, recommends comminution of the coconut pulp and addition of 35 to 60 percent by weight of water to the grated pulp in his patent covering the production of synthetic coconut water from the coconut. Water is added at a temperature ranging preferably from $100^{\circ}$ to $150^{\circ} \mathrm{F}$., but water may be used at room temperature. Siddappa et al. (21) added 75 percent by weight of water and

1 Food Technologist, Research Assistant, and Research Assistant, respectively, Food Technology Laboratory, Agricultural Experiment Station, Mayagüez Campus, University of P.R., Río Piedras, P.R.

2 Italic numbers in parentheses refer to Literature Cited page 173. 
heated the mixture to $122^{\circ} \mathrm{F}$. before pressing to extract the coconut milk, followed by a second extraction with the addition of 37 percent by weight of water to the press-cake, then mixing and pressing it a second time. Roxas (19) heated the comminuted coconut pulp to $170^{\circ}-180^{\circ} \mathrm{F}$., separated part of the milk in a centrifugal operation, and pressed the solid residue to obtain the rest of the coconut milk. Lava (10) comminuted the coconut pulp and added water at a temperature ranging from $72^{\circ}$ to $212^{\circ} \mathrm{F}$., but failed to show what effect the different temperatures have. The amount of water added may vary up to five times the weight of the coconut pulp. Pressing operations may be repeated two or three times depending on the amount of oil retained by the press-cake. He recommended that the temperature of the mass of comminuted coconut pulp and water should be between $72^{\circ} \mathrm{F}$. and $140^{\circ} \mathrm{F}$.

Iopez-Irizarry (11) prepared coconut milk by adding alcohol to the comminuted pulp in a 25-percent-by-weight proportion. He boiled the water from the coconuts in a 50-percent-by-weight proportion and added it to the alcohol-pulp mash. A second pressing was recommended, adding an amount of boiling tap water to the press-cake equal to the weight of the coconut water used in the first pressing.

Wolf (22) recommended the addition of water at $150^{\circ}$ to $170^{\circ} \mathrm{F}$. in an amount five times the weight of the coconut pulp, for the extraction of coconut milk and the straining of the mixture to separate the solid particles. Clemente and Villacorte (7) prepared the coconut milk by hydraulic pressing of the comminuted pulp. They did not use water or raise the temperature of the mash before pressing.

Robledano and Ruiz (20) prepared coconut milk by comminuting the coconut pulp, pre-pressing the grated pulp, and flaking and pressing the cake to obtain additional milk. Popper et al. (18) suggested pressing the comminuted coconut pulp with or without the addition of coconut water.

The available literature contains little information concerning the effect of temperature on the mash, amount of water to be added, and pressures employed in the extraction of coconut milk. The following report furnishes data resulting from experiments conducted to determine the effects on yield of coconut milk and the fat-content of extracts by different amounts and temperatures of water.

\section{MATERIALS AND METHODS}

The coconuts used in the experiments were purchased at the fresh-produce market. They were husked and unclassified as to size. After sorting before processing, the nuts were discarded which were cracked, soft in the eye at the embryo end of the nut, or immature.

One hundred coconuts were used for each experiment. They were heated 
to $307^{\circ} \mathrm{F}$. ( 60 pounds steam) for 8 minutes in a high-pressure vessel (5). The retort was equipped for a fast coming up and instant release of pressure during the operation. Immediately after the heat treatment the coconuts were broken in a coconut breaking machine (6). The broken nuts were carried by a conveyor to a sorting table where loose pieces of pulp were separated and fed into a washing reel. The clean pulp was weighed and ground in a hammer mill equipped with a No. 3 screen which had thirty-six, 1/8-inch diameter perforations per square inch. Water was added to the pulp in the comminuting mill in experiments calling for addition of either cold (tap) or hot water. ${ }^{3}$ Water was added in various amounts; from 0 , to an amount equal to the weight of the pulp used in the experiment (1:1 proportion by weight). The water was added in a manner permitting it to come in contact with the largest possible amount of comminuted pulp.

The coconut milk was separated with a hydraulic press, using two nylon press-cloths and aluminum press racks. Appropriate quantities of comminuted pulp were wrapped, first in a finely- and then in a coarsely-woven nylon cloth. The prepared packs were loaded on the press platen, placing a press rack between packs to provide drainage for the milk pressed out during the pressing operation. The pressure applied throughout was 140 pounds per square inch. The equipment employed automatically controlled set pressure.

After pressing, samples were taken from the coconut press-cake for the determination of fat ( $(9)$ and moisture content (2). Weight of the press-cake was recorded at this time.

Coconut milk, as it comes from the press, contains finely divided coconut pulp. To remove these particles, the milk was centrifuged by means of a low-speed, solid-basket centrifuge, run at 1,100 r.p.m. This operation yielded the coconut milk plus a solid sludge that remained in the centrifuge basket, both of which were weighed. Samples of the coconut milk were taken for fat- and moisture-content determinations.

\section{RESULTS AND DISCUSSION}

Table 1 furnishes data resulting from extracting coconut milk with water at temperatures ranging from $80^{\circ}$ to $86^{\circ} \mathrm{F}$. The addition of water to the pulp in weight ratios varying from 0:4 to 4:4 (water:pulp) tends to increase efficiency of the extraction process. A progressive trend occurs in the extraction as the amount of water is increased. This increase in extraction in terms of average values represents about 10 percent of the coconut pulp used.

The data resulting from extraction with hot water $\left(190^{\circ}\right.$ to $200^{\circ} \mathrm{F}$.) also

3 The temperature for cold water varied from $80^{\circ}$ to $86^{\circ} \mathrm{F}$; for hot water, from $190^{\circ}$ to $200^{\circ} \mathrm{F}$. 
TaBLE 1.-Results obtained from pilot plant tests to extract coconut milk using cold $\left(80^{\circ}\right.$ to $86^{\circ} \mathrm{F}$.) and hot $\left(190^{\circ}\right.$ to $800^{\circ} \mathrm{F}$.) water in different proportions

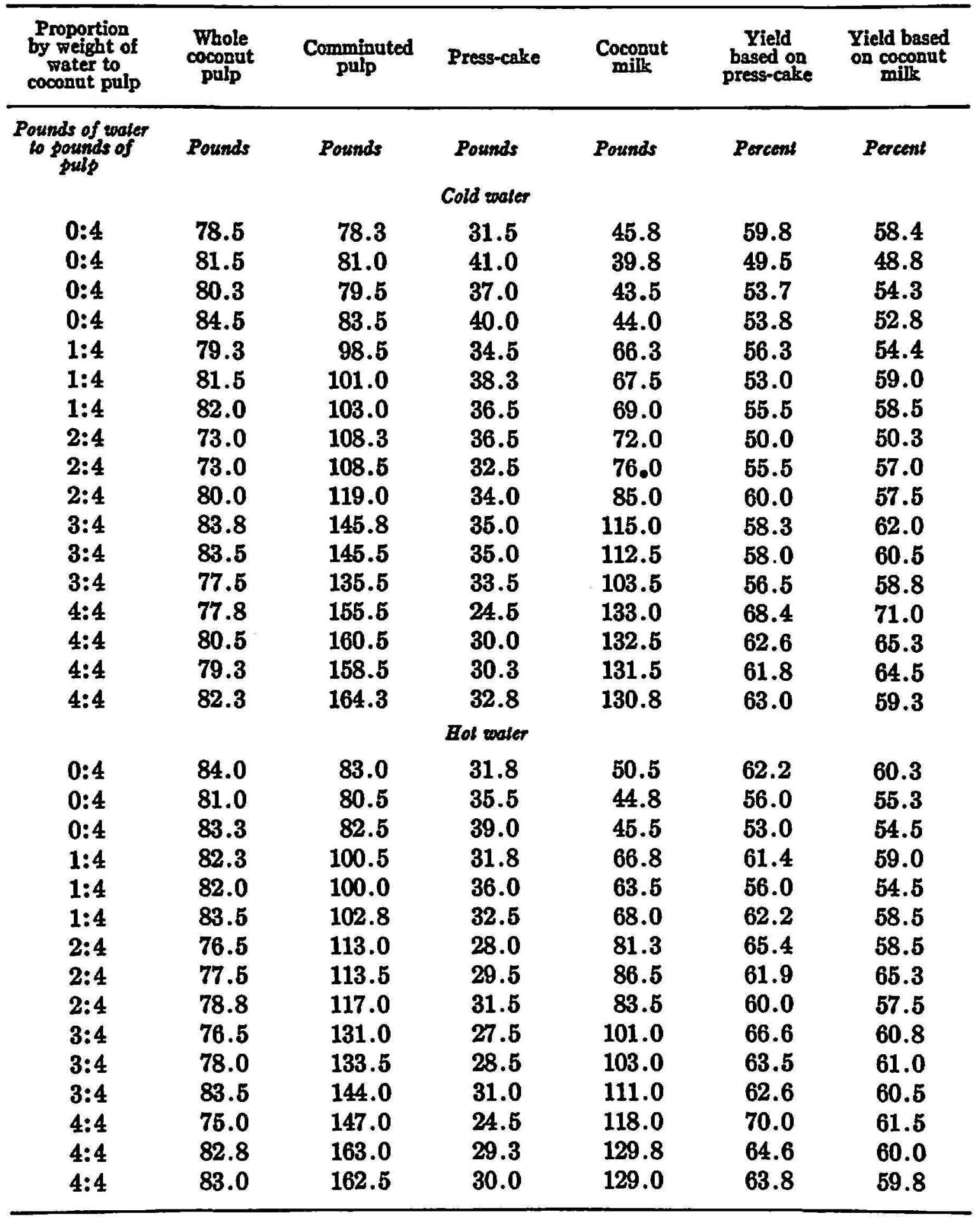

are presented in table 1. These also show an increasing tendency in the extraction as the amount of water is increased although the effect is not as well marked as with tap water. The press-cake calculations show a higher percentage yield than those from the coconut milk. The difference is close to 5 percent. 
TABLE 2.-Chemical analyses of coconul milk and press-cake oblained from extraclion experiments using cold $\left(80^{\circ} 1086^{\circ} \mathrm{F}.\right)$ and hot $\left(190^{\circ}\right.$ to $200^{\circ} \mathrm{F}$.) water in differenl proportions

\begin{tabular}{|c|c|c|c|c|c|c|}
\hline \multirow{2}{*}{$\begin{array}{l}\text { Proportion by } \\
\text { weight of water } \\
\text { to coconut pulp }\end{array}$} & \multicolumn{3}{|c|}{ Coconut milk } & \multicolumn{3}{|c|}{ Coconut press-cake } \\
\hline & $\begin{array}{c}\text { Water } \\
\text { content }\end{array}$ & ${ }^{\circ}$ Brix & $\begin{array}{l}\text { Fat content } \\
\text { wet-basis }\end{array}$ & $\begin{array}{l}\text { Water } \\
\text { content }\end{array}$ & $\begin{array}{l}\text { Fat content } \\
\text { wet-basis }\end{array}$ & $\begin{array}{l}\text { Fat content } \\
\text { dyy-basis }\end{array}$ \\
\hline $\begin{array}{l}\text { Pounds of waler to } \\
\text { pounds of pulp }\end{array}$ & Percent & Degree & Percent & Percent & Percent & Percent \\
\hline \multicolumn{7}{|c|}{ Cold water } \\
\hline $0: 4$ & 44.77 & 11.5 & 42.51 & 35.98 & 39.61 & 62.04 \\
\hline $0: 4$ & 42.95 & 12.1 & 45.12 & 38.07 & 37.36 & 63.56 \\
\hline $0: 4$ & 47.46 & 11.3 & 42.91 & 36.03 & 39.81 & 62.27 \\
\hline $1: 4$ & 59.94 & 9.1 & 26.07 & 35.43 & 40.82 & 63.44 \\
\hline $1: 4$ & 65.15 & 8.4 & 24.86 & 35.77 & 39.05 & 60.72 \\
\hline $1: 4$ & 62.71 & 9.2 & 25.91 & 35.00 & 39.61 & 61.02 \\
\hline $2: 4$ & 76.00 & 6.0 & 19.00 & 39.32 & 37.84 & 62.35 \\
\hline $2: 4$ & 76.75 & 6.1 & 19.84 & 37.72 & 38.29 & 61.48 \\
\hline $2: 4$ & 76.18 & 5.1 & 17.07 & 36.22 & 39.49 & 61.92 \\
\hline $3: 4$ & 78.10 & 4.0 & 15.97 & 36.81 & 38.76 & 61.25 \\
\hline $3: 4$ & 77.63 & 4.0 & 15.62 & 38.22 & 37.44 & 60.66 \\
\hline $3: 4$ & 77.95 & 4.0 & 16.02 & 38.37 & 37.48 & 60.87 \\
\hline $4: 4$ & 77.70 & 4.1 & 15.00 & 33.58 & 39.19 & 59.10 \\
\hline $4: 4$ & 81.63 & 3.6 & 15.03 & 34.03 & 39.60 & 60.04 \\
\hline $4: 4$ & 76.80 & 3.8 & 14.67 & 34.28 & 39.25 & 59.84 \\
\hline \multicolumn{7}{|c|}{ Hol baler } \\
\hline $0: 4$ & 47.15 & 11.3 & 40.96 & 35.83 & 38.40 & 59.86 \\
\hline $0: 4$ & 46.64 & 11.5 & 41.74 & 36.94 & 38.85 & 61.62 \\
\hline $0: 4$ & 46.95 & 11.5 & 42.51 & 38.27 & 37.15 & 60.17 \\
\hline $1: 4$ & 62.24 & 8.5 & 29.55 & 34.89 & 40.29 & 61.88 \\
\hline $1: 4$ & 66.63 & 8.1 & 26.36 & 35.70 & 39.54 & 61.49 \\
\hline $1: 4$ & 60.15 & 8.8 & 30.04 & 34.99 & 40.12 & 61.72 \\
\hline $2: 4$ & 69.45 & 5.9 & 23.75 & 35.67 & 38.32 & 59.33 \\
\hline $2: 4$ & 71.02 & 6.2 & 19.76 & 32.89 & 41.17 & 61.33 \\
\hline $2: 4$ & 70.19 & 7.4 & 20.89 & 34.46 & 39.45 & 60.19 \\
\hline $3: 4$ & 71.61 & 5.1 & 21.79 & 33.84 & 38.52 & 58.22 \\
\hline $3: 4$ & 76.49 & 5.0 & 18.54 & 32.61 & 40.79 & 60.53 \\
\hline $3: 4$ & 76.02 & 5.1 & 16.80 & 34.04 & 40.64 & 61.12 \\
\hline $4: 4$ & 77.75 & 4.7 & 15.23 & 32.21 & 39.89 & 58.84 \\
\hline $4: 4$ & 83.87 & 4.2 & 11.36 & 31.54 & 41.52 & 60.64 \\
\hline $4: 4$ & 77.28 & 4.2 & 15.23 & 32.97 & 40.29 & 60.11 \\
\hline
\end{tabular}

The data resulting from chemical analyses of the coconut milk and presscake are presented in table 2 . These provide more information about the efficiency of the treatments.

Variations in the solid and fat content of the coconut mills obtained by extracting with cold and hot water appear to follow the expected dilution effect. 
The data shows that hot water does not materially increase either yield or quality of the coconut milk extracted. The increase in percentage-yield of coconut milk resulting from larger amounts of water for extraction must be considered separately depending on the purpose of the extraction. If the coconut milk is to be used diluted, addition of water in the extraction process is justified. If the milk is to be used in a concentrated form, it might be more economical and advantageous to extract without addition of water.

\section{SUMMARY}

Studies were conducted on the extraction of coconut milk. Cold water $\left(80^{\circ}\right.$ to $86^{\circ} \mathrm{F}$.) and hot water $\left(190^{\circ}\right.$ to $200^{\circ} \mathrm{F}$.) was added to the coconut pulp in different proportions by weight. Water-addition tests were made, the ratio of water to pulp varied from $0: 4$ to $4: 4$ by weight.

The results indicate that a gradual increase occurs in the percentageyield of coconut milk as the ratio of water to pulp is increased from $0: 4$ to 4:4. The data shows that when the coconut milk is extracted using equal weights of water and coconut pulp (4:4 ratio), the yield is 8 to 10 percent higher than when no water is added (0:4 ratio). The results obtained from the use of cold water as compared with hot water were about the same.

Chemical analyses of the coconut milk show that the fat content of both extracts is very similar with either hot or cold water. The same observation was made concerning the fat content of the press-cake.

\section{RESUMEN}

Se estudió el procedimiento de extraer la leche de coco añadiendo agua fría (de $80^{\circ}$ a $86^{\circ} \mathrm{F}$.) y agua caliente (de $190^{\circ}$ a $200^{\circ} \mathrm{F}$.), en proporciones de peso de agua a pulpa que variaron de $0: 4$ a $4: 4$.

Los resultados obtenidos en estas pruebas indican que el porcentaje de leche de coco recuperado aumenta gradualmente, según varie la cantidad de agua que se añada, desde cero hasta una cantidad igual al peso de la pulpa usada. Cuando la extracción se hace usando igual peso de agua y pulpa de coco, se obtiene un rendimiento de 8 a 10 porciento mayor que el que se obtiene sin añadir agua. Se encontró también que el uso del agua caliente en la extracción no mejora el rendimiento de leche de coco.

Los análisis químicos que se hicieron demostraron que la temperatura del agua, fuese ésta fría o caliente, no afectó sustancialmente el contenido de grasa en la leche de coco y en la cachipa.

\section{LITERATURE CITED}

1. Aboy-de-Valldejuli, C., Cocina Criolla 6th ed., The Alpine Press, Inc., Boston, Mass., 1962.

2. Association of Official Agricultural Chemists (A.O.A.C.), Official and Tentative Methods of Analyses, 10th. ed., Washington. D. C., 1965. 
3. Buchanan, D. W., Coconut Nutrition, Temperate to Tropical Fruit Nutrition, Norman F. Childer, Editor, Somerset Press, Inc., Somerville, New Jersey, 1966.

4. Cabanillas, B., Ginorio, C., and Q.-de-Mercado, C., Cocine a Gusto 5th ed., Ediciones Rumbos, Ramblas 23, Barcelona, Espafia, 1960.

5. Cancel, L. E., Method of Shelling Coconuts, U.S. Patent 3,225,804, 1965.

6. Cancel, L. E., Coconut Breaking Machine, U.S. Patent Application Serial No. 830,621 .

7. Clemente, A., and Villacorte, M., Some Colloidal Properties of Coconut Milk, Phil. J. of Sci. s: 7-10, 1933.

8. Coconut Research Institute, Coconut as Food, Ceylon Coconut Quart. 5: 45, 101, 104, 237, 1954.

9. Cox, H. E., and Pearson, D., Rose-Gottlieb and Majonnier Process, The Chemical Analyses of Foods, Chemical Publishing Co., New York, N.Y., 341-342, 1962.

10. Lava, V. G., Oil Recovery, U.S. Patent 2,101,371, 1937.

11. López-Irizarry, R., Method of Producing Food Products from Coconuts, U.S. Patent 2,712,502, 1952.

12. Luke, E., Production of Synthetic Coconut Water, U.S. Patent 2,776,891, 1957.

13. Nathanael, W. R. N., Annual Report of the Coconut Research Institute for 1960, Ceylon Coconut Quart. 12: 30, 1961.

14. Nathanael, W. R. N., Visit to the Philippine Islands Report, Ceylon Coconut Quart. 10: 9, 29, 33, 35, 1959.

15. Nathanael, W. R. N., Coconut Research Institute of Ceylon Report, Ceylon Coconut Quart. 5: 108, 1954.

16. Nathanael W. R. N., Chemical and Technological Investigations on Coconut Products, Ceylon Coconut Quart. 11: 46, 1960.

17. Palad, J. G., Abdon, I. C., Lontoc, A. V., Dimaunahan, L. B., Eusebio, E. C., and Santiago, N., Nutritive value of some foodstuffs processed in the Philippines, Phil. J. Sci. 81 (3): 355-373, 1964.

18. Popper, K., Notter, G. K., and Nury, F. S., New products from coconut-nondairy chip dips and "Cream cheese", Food Process. \& Marketing, December, 1966.

19. Roxas, P. G., Process of Recovering Oils from Oleoginous Meats of Nuts, Beans and Seeds, U.S. Patent 3,083,365, 1963.

20. Robledano, P., and Ruíz-de-Luzuriaga, E., Simple, Direct Extraction of Coconut Oil, Food Eng. 24 (10): 143-44, 1952.

21. Siddappa, G. S., Bathia, B. S., and Lal G., Coconut Milk Concentrate and Powder, Central Food Technological Research Institute (Mysore), Bull. 5, p. 311, 1956.

22. Wolf, H. E., and Abbey, A. F., Process for Preparing a Stable Edible Coconut Water Extract, U.S. Patent 3,076,714, 1963. 